\title{
Location and Properties of an Esterase Activity in Saccharomyces cerevisiae
}

\author{
By G. E. WHEELER AND A. H. ROSE \\ Microbiology Laboratories, School of Biological Sciences, \\ Bath University, Bath
}

(Received I4 July 1972)

INTRODUCTION

Several hydrolytic enzymes, including invertase (Demis, Rothstein \& Meier, 1954) and acid phosphatase (Tonino \& Steyn-Parvé, 1963), are located mainly in the periplasm and cell envelope in yeasts. Lampen (1968) and Suomalainen \& Oura (I97I) have reviewed information on periplasmic and cell-envelope enzymes in yeasts. Matile \& Wiemken ( I967) also detected a number of hydrolytic enzymes in vacuoles isolated from lysed sphaeroplasts of Saccharomyces cerevisiae by flotation in Ficoll. Among the enzymes detected in the vacuoles, which they suggested function as lysosomes in yeast, were proteases, ribonuclease and an esterase that catalyses hydrolysis of $p$-nitrophenyl acetate. The present paper reports further on the location of esterase activity in Sacch. cerevisiae and describes briefly some properties of this activity.

\section{METHODS}

Saccharomyces cerevisiae NCYC 366 was grown aerobically, in batch culture as described by Patching \& Rose (1971) or in continuous culture under conditions of glucose limitation as reported by Hunter \& Rose (1972). Except when otherwise stated, organisms were harvested from mid exponential-phase batch cultures (containing 0.20 to $0.25 \mathrm{mg}$ dry wt $/ \mathrm{ml}$ ) by centrifuging at $\mathrm{I} 500 \mathrm{~g}$ for $\mathrm{I0} \mathrm{min}$ at $3{ }^{\circ} \mathrm{C}$. Extracts of organisms were prepared by centrifuging ( $1500 \mathrm{~g}$ for Io $\mathrm{min}$ ) suspensions of organisms (200 $\mathrm{mg}$ dry wt organisms and $20 \mathrm{~g}$ Ballotini beads, grade II, in $\left.20 \mathrm{ml} 67 \mathrm{mM}-\mathrm{KH}_{2} \mathrm{PO}_{4} ; \mathrm{pH} 4.5\right)$ in a Braun homogenizer. Esterase activity (EC. 3.I.I.I) was assayed by using I-naphthyl acetate as substrate at pH 6.5 by the procedure described by Wheeler, Coleman \& Finean (1972). Leucine aminopeptidase activity (EC. 3.4.I.I) was assayed by the method of Goldbarg \& Rutenberg (I958), modified by using tris- $\mathrm{HCl}$ buffer ( $\mathrm{pH} \mathrm{6.8)} \mathrm{in} \mathrm{a} \mathrm{reaction} \mathrm{mixture} \mathrm{containing} 2 \mathrm{~mm}$ substrate and $\mathrm{O} \cdot \mathrm{I} \mathrm{mM}-\mathrm{CoCl}_{2}$.

Sphaeroplasts were prepared by suspending washed mid exponential-phase organisms (IO mg dry wt $/ \mathrm{ml}$ ) in $0.1 \mathrm{M}$-citrate-phosphate buffer $\left(\mathrm{pH} 6.0\right.$ ) containing Io $\mathrm{mM}-\mathrm{MgCl}_{2}$, I.O M-sorbitol, and glucanase ( 3 units/mg dry wt yeast) from basidiomycete QM 806 (Huotari, Nelson, Smith \& Kirkwood, 1968). The suspension was incubated with gentle shaking at $30{ }^{\circ} \mathrm{C}$, and formation of osmotically sensitive sphaeroplasts monitored by diluting $0.1 \mathrm{ml}$ portions into $2.9 \mathrm{ml}$ water, shaking, and following the decrease in extinction at $660 \mathrm{~nm}$. Sphaeroplast formation was always complete after about 90 min of incubation. Sphaeroplasts were removed from the glucanase digest by centrifuging at $1500 \mathrm{~g}$ for Io $\mathrm{min}$. The supernatant was centrifuged at $76000 \mathrm{~g}$ for $90 \mathrm{~min}$, and the esterase activity of the supernatant measured. Sphaeroplasts were disrupted by using a Potter-Elvehjem homogenizer, and the esterase activity of the suspension also measured. 
Table I. Esterase and leucine aminopeptidase activities of Saccharomyces cerevisiae $\mathrm{NCYC} 366$ and of sphaeroplasts from the yeast

$\begin{array}{cccc}\text { Enzyme } & \begin{array}{c}\text { Activity in } \\ \text { intact organisms } \\ (\mu \mathrm{mol} / \mathrm{mg} \text { dry wt } / \mathrm{h})\end{array} & \begin{array}{ccc}\text { Sphaeroplasts } \\ \text { Esterase }\end{array} & \begin{array}{c}\text { Sphaeroplast- } \\ \text { free } \\ \text { glucanase digest }\end{array} \\ \text { Leucine aminopeptidase } & 0.14 \pm 0.0 \mathrm{I} & 23 & 77 \\ 0.0 \mathrm{I} & 86 & 14\end{array}$

\section{RESULTS}

Esterase activity was detectable in extracts of Saccharomyces cerevisiae $\mathrm{NCYC}_{3} 66$, but the activity, on an organism dry-weight basis, was greater in intact organisms, which suggests that the activity was located at the cell envelope. This supposition was confirmed when it was shown that the bulk of the esterase activity was released into the supernatant liquid when organisms were converted into sphaeroplasts by digestion with a $\beta$-glucanase from basidiomycete QM806 (Huotari et al. 1968; Table I). By contrast, most of the leucine aminopeptidase activity remained in the sphaeroplasts. Additional evidence for a periplasmic location of the esterase activity was obtained histochemically, by using I-naphthyl acetate coupled to Fast Blue RR salt (Gomori, 1952), when the dye formed as a result of enzyme activity was detected in the yeast wall.

Esterase was not readily released from intact organisms. Activity could not be detected in filtrates from cultures containing 0.20 to $0.25 \mathrm{mg}$ dry wt $/ \mathrm{ml}$ or in filtrates from cultures $(0.5 \mathrm{mg}$ dry $\mathrm{wt} / \mathrm{ml})$ grown at $0.10 \mathrm{~h}^{-1}$ in a chemostat under glucose limitation (Hunter \& Rose, 1972). Organisms from these chemostat cultures had a similar esterase activity to those from mid exponential-phase batch cultures. Esterase activity was high in organisms in the early exponential phase of growth, but thereafter declined. Organisms in cultures containing 0.02 dry $\mathrm{wt} / \mathrm{ml}$ had an activity of $0.80 \mu \mathrm{mol} / \mathrm{mg}$ dry wt $/ \mathrm{h}$, whereas in cultures containing $\mathrm{I} \cdot 00 \mathrm{mg}$ dry $\mathrm{wt} / \mathrm{ml}$ the activity was $0.15 \mu \mathrm{mol} / \mathrm{mg}$ dry wt/h. The decrease in activity of batch-grown organisms cannot be attributed to secretion of enzyme, nor would it appear to have been caused by relocation of the activity in the yeast since sphaeroplasts from mid exponential-phase cultures were low in esterase activity (Table I).

The optimum $\mathrm{pH}$ value for activity of esterase in glucanase-treated suspensions of organisms that had been centrifuged at $1500 \mathrm{~g}$ for $10 \mathrm{~min}$ to remove sphaeroplasts was 6.5 . The enzyme released from organisms by glucanase digestion had a relatively low affinity for I-naphthyl acetate as indicated by the $K_{m}$ value of I 33 .

Matile \& Wiemken ( 1967 ) used $p$-nitrophenyl acetate as substrate in their esterase assays. The enzyme released by glucanase digestion of Saccharomyces cerevisiae NCYC 366 also catalyses hydrolysis of $p$-nitrophenyl acetate, but this substrate was not used routinely since, in our hands, it was unstable. Since Sacch. cerevisiae contains appreciable amounts of sterol esters (Maguigan \& Walker, I940; Adams \& Parks, I967; Hunter \& Rose, I972), we tested the ability of enzyme released from glucanase-treated organisms to hydrolyse these compounds. A ${ }^{14} \mathrm{C}$-labelled sterol ester fraction was isolated by preparative thin-layer chromatography (Hunter \& Rose, 1972) of lipids from Sacch. cerevisiae NCYC 366 grown in a defined medium (I 1; Patching \& Rose, I97I) supplemented with [U-14 C] acetate $(0.215 \mu \mathrm{mol} ; \mathrm{I} 2.5 \mu \mathrm{Ci})$. The enzyme hydrolysed the labelled sterol esters as shown by the detection of labelled free sterol and fatty acid after thin-layer chromatography of the 
reaction mixture. However, Tween 80 (polyoxyethylene sorbitan mono-oleate), which is used to supply unsaturated fatty acid to anaerobically grown Sacch. cerevisiae (Andreasen \& Stier, 1954), was not detectably hydrolysed by esterase released by glucanase digestion of aerobically grown Sacch. cerevisiae NCYC 366 ; nor was the Tween hydrolysed by esterase released from Sacch. cerevisiae NCYC 366 grown anaerobically, with medium supplemented with ergosterol or cholesterol $(5 \mathrm{mg} / \mathrm{l})$ and Tween $80(2 \mathrm{~g} / \mathrm{l})$, and sparged with oxygen-free nitrogen gas. Anaerobically grown organisms had an esterase activity that was not significantly different from that of aerobically grown organisms.

\section{DISCUSSIONS}

Although Matile \& Wiemken (1967) reported esterase activity only in isolated vacuoles from Saccharomyces cerevisiae, our data show that, in our strain at least, the bulk of this activity is in the periplasmic space. This finding is not at variance with the report of Matile \& Wiemken (1967) since these workers did not assay esterase activity in organisms before and after removal of the wall. However, our finding that the majority of the aminopeptidase activity was retained in sphaeroplasts does contradict Matile (1969) who reported that, in another strain of Sacch. cerevisiae, only $7.2 \%$ of the aminopeptidase activity is retained in the sphaeroplast. The ability of the mainly periplasmically located esterase in Sacch. cerevisiae NCYC 366 to hydrolyse sterol esters is of some interest since these lipids are concentrated largely in low-density vesicles and also in vacuoles in Sacch cerevisiae (Hunter, I972; G. E. Wheeler \& A. H. Rose, unpublished observations). One possible role for the periplasmically located esterase may be in the release of vesicle-associated material from the plasma membrane, either during wall growth (Sentandreu \& Northcote, 1969) or secretion of internally synthesized enzymes such as invertase (Beteta \& Gascón, 197I) and glucanase (Matile, Cortat, Wiemken \& Frey-Wyssling, 1971). If a relationship of this type does exist between the intracellular vesicles and plasma membrane, it might explain the discrepancies between the report by Matile (1969) and our data on the cellular location of aminopeptidase. Thus growth conditions could affect the rate of release of vesicular-bound material, and possibly, therefore, the proportions of this activity located in vesicles and in the periplasmic space. The inability of the periplasmically located esterase from aerobically or anaerobically grown Sacch. cerevisiae NCYC 366 to catalyse hydrolysis of Tween 80 at first seemed puzzling. Tween 80 is a large molecule, and it is unlikely that it can penetrate the plasma membrane of the yeast. One possibility is that, when Tween 80 is used to support anaerobic growth of Sacch.cerevisiae, the small amounts (about $10 \%$ ) of free fatty acid in the Tween provide the essential nutrient. When we extracted free fatty acids from Tween 80 by chromatography on a silica-gel column, the extracted Tween was either unable to support anaerobic growth of Sacch. cerevisiae or did so less efficiently.

This research was supported by grants $(\mathrm{B} / \mathrm{SR} / 5724$ and $\mathrm{B} / \mathrm{RG} / \mathrm{I} 82)$ from the Science Research Council. Our thanks are due to Mrs Diane Arkell for valuable technical assistance and to $\mathrm{Mr} \mathbf{J}$. A. Hossack for advice on anaerobic yeast cultures. 


\section{REFERENCES}

Adams, B. G. \& Parks, L. W. (1967). Evidence for dual physiological forms of ergosterol in Saccharomyces cerevisiae. Journal of Cellular and Comparative Physiology 70, I6I-168.

Andreasen, A. A. \& Stier, T. J. B. (I954). Anaerobic nutrition of Saccharomyces cerevisiae. II. Unsaturated fatty acid requirement for growth in a defined medium. Journal of Cellular and Comparative Physiology $43,27 I-282$.

BeteTA, P. \& GASCón, S. (I971). Localization of invertase in yeast vacuoles. Federation of European Biochemical Societies Letters $x_{3}, 297-300$.

Demis, D. J., Rothstein, A. \& Meier, R. (1954). The relationship of the cell surface to metabolism. X. The location and function of invertase in the yeast cell. Archives of Biochemistry and Biophysics 48, 55-62.

Goldbarg, J. A. \& Rutenberg, A. M. (1958). The colorimetric determination of leucine aminopeptidase in urine and serum of normal subjects and patients with cancer and other diseases. Cancer (New York) II, 283-29I.

Gomori, G. (1952). Microscopic Histochemistry, p. 207. Chicago, Illinois: University of Chicago Press.

HUNTER, K. (1972). The lipid composition of Saccharomyces cerevisiae NCYC 366. Ph.D. Thesis, University of Bath.

Hunter, K. \& Rose, A. H. (1972). Lipid composition of Saccharomyces cerevisiae as influenced by growth temperature. Biochimica et biophysica acta 260, 639-653.

Huotari, F. I., Nelson, T. E., Smith, F. \& Kirkwood, S. (I968). Purification of an exo- $\beta$-D-(I $\rightarrow 3$ )glucanase from basidiomycete QM806. Journal of Biological Chemistry 243, 952-956.

LAMPEN, J. O. (1968). External enzymes of yeast; their nature and function. Antonie van Leeuwenhoek Journal of Microbiology and Serology 34, I-I8.

Maguigan, W. H. \& Walker, E. (1940). Sterol metabolism of micro-organisms. I. Yeast. Biochemical Journal 34, 804-8 r 3 .

MATILE, P. (I 969). Utilization of peptides in yeasts. Proceedings of the 2 nd International Symposium on Yeasts, Bratislava, I966, p. 503.

Matile, P., Cortat, M., Wiemken, A. \& Frey-Wyssling, A. (i97I). Isolation of glucanase-containing particles from budding Saccharomyces cerevisiae. Proceedings of the National Academy of Sciences of the United States of America 68, 636-640.

Matile, P. \& Wiemken, A. (I967). The vacuole as the lysosome of the yeast cell. Archiv für Mikrobiologie 56, $148-155$.

Patching, J. W. \& Rose, A. H. (I971). Cold osmotic shock in Saccharomyces cerevisiae. Journal of Bacteriology I08, $45 \mathrm{I}-458$.

SEntandreu, R. \& NorthCOTE, D.H. (1969). The formation of buds in yeast. Journal of General Microbiology 55, 393-398.

Suomalainen, H. \& Oura, E. (I97I). Yeast nutrition and solute uptake. In The Yeasts, vol. 2, pp. 3-74. Edited by A. H. Rose and J. S. Harrison. London: Academic Press.

Tonino, G. J. M. \& Steyn-Parvé, E. P. (1963). Localization of some phosphatases in yeast. Biochimica et biophysica acta 67, 453-469.

Wheeler, G. E., Coleman, R. \& Finean, J. B. (1972). Cholinesterase activities in subcellular fractions of rat liver. Biochimica et biophysica acta 255, 9I 7-930. 